\title{
Pengaruh Paket Remaja Sehat Terhadap Pengetahuan Dan Sikap Remaja Tentang Dampak Pernikahan Usia Dini Di Cilacap
}

\author{
${ }^{1}$ Kusmawati \\ ${ }^{2}$ Idriani \\ ${ }^{3}$ Suhendar Sulaeman
}

${ }^{1,2,3}$ Universitas Muhammadiyah Jakarta, Indonesia

\begin{abstract}
Alamat Korespondensi:
Kusmawati

Universitas Muhammadiyah Jakarta

Email: kusmawati.nurse@gmail.com
\end{abstract}




\begin{abstract}
ABSTRAK
Pendahuluan masa remaja merupakan suatu masa kehidupan individu dimana terjadi eksplorasi psikologis untuk menentukan identitas diri. Menikah di usia remaja menjadi topik menarik dan menjadi sasaran utama pada kerangka kerjasama SDGs (Sustainable Development Goals). Dampak dari pernikahan usia dini adalah menurunnya kesehatan reproduksi, beban ekonomi yang semakin berat, kekerasan dalam rumah tangga dan penyakit menular seksual. Metode Penelitian ini kuantitatif dengan menggunakan metode pre-eksperimental design dengan pendekatan one group pre test and post test design. Populasi dalam penelitian ini adalah remaja perempuan usia 17-19 tahun Di Desa Sadabumi Kecmatan Majenang Kabupaten Cilacap. Sampel penelitian ini adalah 67 remaja perempuan. Instrumen pada penelitian ini adalah angket kuesioner kesehatan reproduksi dan dampak pernikahan usia dini yang telah dilakukan uji validitas dan reliabilitas oleh peneliti sebelumnya yaitu Siti Salamah. Hasil penelitian terdapat perbedaan pengetahuan dan sikap remaja tentang dampak pernikahan usia dini sebelum dan sesudah diberikan paket "Remaja Sehat" dengan nilai $p$-value $=0,001(p<0.05)$. Rekomendasi untuk menambah variable baru dengan menggunakan media atau kelompok kontrol.
\end{abstract}

Kata Kunci: Paket Remaja Sehat, Pengetahuan, Sikap, Pernikahan Usia Dini

\begin{abstract}
ABSTRAC
The introduction to adolescence is a period of individual life in which psychological exploration occurs to determine self-identity. Getting married in adolescence is an interesting topic and a major target in the framework of Sustainable Development Goals (SDGs). The impacts of early marriage are declining reproductive health, an increasingly severe economic burden, domestic violence and sexually transmitted diseases. This research method is quantitative by using pre-experimental design method with one group pre test and post test design approach. The population in this study was teenage girls aged 17-19 years in Sadabumi Village Kecmatan Majenang Cilacap Regency. The sample of this study was 67 teenage girls. The instrument in this study is a questionnaire questionnaire on reproductive health and the impact of early marriage that has been conducted validity and reliability tests by the previous researcher, Siti Salamah. The results of the study found differences in adolescent knowledge and attitudes about the impact of early marriage before and after being given the package "Healthy Adolescents" with a value of $p$-value $=0.001$ ( $p<0.05)$. Recommendations for adding new variables by using media or control groups.
\end{abstract}

Keywords: Healthy Teen Package, Knowledge, Attitude, Early Marriage 


\section{PENDAHULUAN}

Usia remaja merupakan masa peralihan seseorang menjadi dewasa yang semula anak-anak, terjadi pertumbuhan dengan ciri-ciri sekunder berupa adanya perubahan psikologi, kognitif, serta tercapainya fertilitas (Soetjiningsih, 2006). Menurut Depkes RI (2007) remaja dapat dibagi menjadi beberapa kategori seperti tahap awal usia 11 sampai 13 tahun, tahap menengah 14 sampai 16 tahun, serta tahap akhir usia 17 sampai 19 tahun.

Dari aspek remaja diantaranya pubertas atau kematangan seksual yang semakin dini dan aksesibilitas terhadap berbagai media serta pengaruh negatif dari teman sebaya menjadikan remaja rentan terhadap perilaku seksual berisiko, mengalami pernikahan di usia dini.

Pernikahan usia dini menjadi topik menarik dan menjadi sasaran utama pada kerangka kerjasama SDGs (Sustainable Development Goals). Pada riset UNICEF (United Nations Children's Fund) tercatat satu dari enam anak perempuan di Indonesia menikah sebelum usia 18 tahun dan mencapai angka 340.000 anak per tahun. Adapula usia di bawah 15 tahun mencapai angka 50.000 anak per tahun. Indonesia menduduki peringkat ke-37 dunia dan peringkat ke2 se-ASEAN sebagai salah satu negaradengan angka pernikahan usia dini yang tinggi menurut
UNDESA (United National Development Economic and Social Affair).

Terjadinya pernikahan usia dini disebabkan oleh beberapa faktor, seperti pola pikir masyarakat/budaya lokal, rendahnya pendidikan masyarakat, rendahnya ekonomi masyarakat, seks bebas dan kehamilan diluar nikah, dan perundang-undangan yang tumpang tindih (Dinas Kesehatan, 2018).

Pengadilan Agama Cilacap, menerima pengajuan pernikahan usia dini periode Januari-Februari 2020, sebanyak 145 pasangan. Masyarakat melakukan pernikahannya di bawah umur atau dibawah usia 20 tahun atau pernikahan usia dini. Faktor adanya pernikahan usia dini disebabkan ketidaktahuan dari pihak orang tua yang memaksakan anaknya untuk menikah dini, serta faktor anak-anak usia dini yang tidak mengetahui dampak pernikahan usia dini (Yulmani,2015).

Pernikahan dibawah usia 20 tahun banyak dampak negatif bagi pasangan usia dini khususnya pada perempuan, organ reproduksi perempuan usia dibawah 20 tahun masih belum matang, sangat rentan terkena kanker mulut rahim 10-20 tahun yang akan datang apabila tersentuh oleh alat kelamin laki-laki, dari segi kesehatan fisik ibu usia muda rentan dengan fisik yang lemah, apalagi disaat hamil dengan usia muda rentan dengan keguguran, berat 
badan bayi lahir rendah, pendarahan serta kekurangan asupan gizi (Yulmani, 2015).

Berbagai upaya telah dilakukan untuk menekan angka pernikahan usia dini di Indonesia. Namun, melihat beberapa data yang ada, muncul pertanyaan mengenai apa yang menyebabkan intervensi atau usaha-usaha yang telah dilakukan belum berhasil menurunkan angka pernikahan usia dini. Berdasarkan fakta dan berbagai penelitian inilah peneliti tertarik untuk mengambil tema pernikahan usia dini yang dialami remaja wanita dan minimnya pengetahuan mengenai kematangan system reproduksi di usia di bawah 20 tahun di wilayah Kabupaten Cilacap peneliti ingin mengetahui pengaruh Paket "Remaja Sehat" terhadap pengetahuan dan sikap remaja terkait dampak pernikahan usia dini di Wilayah Kecamatan Majenang, Kabupaten Cilacap, Provinsi Jawa Tengah tahun 2020.

\section{METODE PENELITIAN}

Penelitian ini adalah penelitian kuantitatif. Penelitian ini menggunakan metode penelitian preeksperimental design dengan pendekatan one group pre test and post test design, yaitu rancangan eksperimen dengan cara sampel diberikan kuesioner (pengukuran) sebelum dan sesudah dilakukan treatment (perlakuan) (Suryana, 2015).

Sampel dalam penelitian ini adalah remaja perempuan berusia 17,18 dan 19 tahun di Desa Sadabumi, Kecamatan Majenang, kabupaten Cilacap, Provinsi Jawa Tengah. Besar sampel dihitung dengan rumus Slovin. Sampel dalam penelitian ini adalah 67 orang remaja perempuan berusia 17, 18 dan 19 tahun di Desa Sadabumi, Kecamatan Majenang, kabupaten Cilacap, Provinsi Jawa Tengah. Teknik pengambilan sampel pada penelitian ini menggunakan Purposive sampling. Purposive sampling adalah teknik pengambilan data dengan pertimbangan tertentu (Sugiyono, 2012). Peneliti menerapkan kriteria inklusi dan ekslusi. Kriteria inklusi dalam penelitian ini yaitu Remaja perempuan usia 17, 18 dan 19 tahun, belum menikah, dapat berkomunikasi dengan baik, dapat baca tulis dan bersedia menjadi responden.

Penelitian ini dilakukan dengan memperhatikan serta memperhatikan etika dalam melakukan penelitian meliputi prinsip-prinsip etika dan informed consent. , aplikasi pada responden sebelum diberikan inform consent peneliti memberikan penjelasan pada responden yang memenuhi kriteria inklusi tentang tujuan, manfaat, prosedur penelitian dan peran responden, kemudian peneliti memberikan kesempatan pada responden tersebut untuk menentukan bersedia atau tidaknya menjadi responden pada 
penelitian ini. Responden bersedia diminta untuk menandatangani pernyataan/inform consent dan lembar edukasi tujuan penelitian. Lembar Infromed consent diberikan kepada responden untuk ditandatangani setelah diberikan penjelasan prosedur penelitian, keuntungan dan kerugian bagi responden serta manfaat dari penelitian. Instrumen yang digunakan pada penelitian ini adalah adalah angket kuesioner kesehatan reproduksi dan dampak pernikahan usia dini yang telah dilakukan uji validitas dan reliabilitas oleh peneliti sebelumnya yaitu Siti Salamah (2016).

Peneliti melakukan kegiatan selama 5 hari dengan memberikan pendidikan kesehatan paket remaja sehat, sebelum memberikan intervensi peneliti membagikan kuesioner untuk melihat pre test, dan setelah diberikan intervensi peneliti memberikan kuesioner kembali untuk melihat post test.

\section{HASIL PENELITIAN}

Karakteristik yang diteliti peneliti ini meliputi usia, pendidikan, pengalaman, dan sumber informasi. Berdasarkan table 1 diketahui bahwa mayoritas responden berusia 18 tahun, mayoritas pendidikan SMA, semua responden pernah mendapatkan pengalaman dan mayoritas sumber informasi yang di dapat dari internet. Berdasarkan table 2 pengetahuan sebelum diberikan paket remaja sehat menunjukkan bahwa dari 67 responden, jumlah responden yang berpengetahuan baik sebanyak 4 orang $(6,0 \%)$, yang berpengetahuan cukup sebanyak 52 orang (77,6\%), dan yang berpengetahuan kurang sebanyak 11 orang $(16,4 \%)$. Pengetahuan sesudah diberikan paket remaja sehat menunjukkan bahwa dari 67 responden, jumlah responden yang berpengetahuan baik sebanyak 52 orang $(77,6 \%)$, yang berpengetahuan cukup sebanyak 13 orang $(19,4 \%)$, dan yang berpengetahuan kurang sebanyak 2 orang (3,0\%).

Berdasarkan table 3 sikap sebelum diberikan paket remaja sehat menunjukkan bahwa dari 67 responden, jumlah responden dengan sikap baik sebanyak 54 orang $(80,6 \%)$, dan yang tidak baik sebanyak 13 orang $(19,4 \%)$. Sikap sesudah diberikan paket remaja sehat menunjukkan bahwa dari 67 responden, jumlah responden dengan sikap baik sebanyak 65 orang $(97,0 \%)$, dan yang tidak baik sebanyak 2 orang $(3,0 \%)$. Hasil uji normalitas berdasarkan tabel 4 didapatkan nilai skor pegetahuan dan sikap remaja sebelum dan sesudah diberikan intervensi paket remaja sehat diperoleh nilai $p$ value $>0,05$, sehingga dapat disimpulkan bahwa data berdistribusi normal, maka jenis uji yang digunakan dalam penelitian ini adalah uji dependent $t$ test atau paired $t$ - 
test. Analisis bivariat terdiri dari pengetahuan dan sikap remaja tentang dampak pernikahan usia dini pre-test dan post-test pemberian paket Remaja Sehat di Wilayah Kecamatan Majenang, Kabupaten Cilacap, Provinsi Jawa Tengah. Pengetahuan Remaja Pre-Test dan PostTest Pemberian Pendidikan Kesehatan Paket Remaja Sehat di Wilayah Kecamatan Majenang, Kabupaten Cilacap, Provinsi Jawa Tengah.

Berdasarkan table 5 distribusi tingkat pengetahuan remaja sebelum dan sesudah pemberian paket remaja sehat, diperoleh nilai rata-rata responden sebelum diberikan paket remaja sehat adalah 1,90 dan sesudah diberikan paket remaja sehat adalah 2,75. Hasil uji statistik paired t-test didapatkan nilai $p$-value $=0,000(p<0.05)$ yang berarti ada pengaruh paket Remaja Sehat terhadap pengetahuan remaja tentang dampak pernikahan usia dini di Wilayah Kecamatan Majenang, Kabupaten Cilacap, Provinsi Jawa Tengah tahun 2020.

Berdasarkan table 6 distribusi tingkat sikap remaja sebelum dan sesudah pemberian paket remaja sehat, diperoleh nilai rata-rata responden sebelum diberikan paket remaja sehat adalah 1,81 dan sesudah diberikan paket remaja sehat adalah 1,97. Hasil uji statistik paired t-test didapatkan nilai $p$-value $=0,001 \quad(p<0.05)$ yang berarti ada pengaruh paket remaja sehat terhadap sikap remaja tentang dampak pernikahan usia dini di Wilayah Kecamatan Majenang, Kabupaten Cilacap, Provinsi Jawa Tengah tahun 2020.

\section{PEMBAHASAN}

\section{Pengaruh "Paket Remaja Sehat"} Terhadap Pengetahuan Remaja Tentang Dampak Pernikahan Usia Dini

Berdasarkan hasil dari analisis data diperoleh nilai rata-rata pengetahuan responden sebelum diberikan paket remaja sehat adalah 1,90 dan sesudah diberikan paket remaja sehat adalah 2,75. Dilihat dari nilai rata-rata sebelum dan sesudah diberikan paket remaja sehat terdapat peningkatan nilai rata-rata yang signifikan hasil uji statistik menunjukkan nilai $p$ value $=0,000(p<0.05)$ yang berarti ada pengaruh paket remaja sehat terhadap pengetahuan remaja tentang dampak pernikahan usia dini di Wilayah Kecamatan Majenang, Kabupaten Cilacap, Provinsi Jawa Tengah tahun 2020.

Hasil penelitian diatas menunjukkan bahwa pendidikan kesehatan dapat meningkatkan pengetahuan remaja tentang dampak pernikahan usia dini terhadap kesehatan reproduksi dalam bentuk paket remaja sehat. Hal ini sebagai akibat dari penerimaan informasi yang baru, serta pemberian media booklet yang setidaknya dapat dibaca oleh responden untuk menambah pemahaman dan informasi 
tentang kesehatan reproduksi terhadap dampak pernikahan usia dini.

Hasil penelitian yang dilakukan oleh Arosna (2014), menunjukkan bahwa terdapat pengaruh pendidikan kesehatan reproduksi terhadap pengetahuan mahasiswa di FIK-UMS. Hal ini sejalan dengan penelitian yang dilakukan oleh Santhya (2010), menyatakan bahwa efektivitas program penyuluhan kesehatan dalam meningkatkan pengetahuan remaja Nigeria tentag pernikahan dini memberikan pengaruh positif karena hasil uji statistik menunjukkan $p$-value 0,000.

Pengadilan Agama Cilacap, menerima pengajuan pernikahan usia dini periode Januari-Februari 2020, sebanyak 145 pasangan. Masyarakat melakukan pernikahannya di bawah umur atau dibawah usia 20 tahun atau pernikahan usia dini. Faktor adanya pernikahan usia dini disebabkan ketidaktahuan dari pihak orang tua yang memaksakan anaknya untuk menikah dini, serta faktor anak-anak usia dini yang tidak mengetahui dampak pernikahan usia dini (Yulmani,2015).

Pernikahan dibawah usia 20 tahun banyak dampak negatif bagi pasangan usia dini khususnya pada perempuan, organ reproduksi perempuan usia dibawah 20 tahun masih belum matang, sangat rentan terkena kanker mulut rahim 10-20 tahun yang akan datang apabila tersentuh oleh alat kelamin laki-laki, dari segi kesehatan fisik ibu usia muda rentan dengan fisik yang lemah, apalagi disaat hamil dengan usia muda rentan dengan keguguran, berat badan bayi lahir rendah, pendarahan serta kekurangan asupan gizi (Yulmani, 2015).

Penelitian ini sejalan dengan penelitian yang dilakukan oleh Kartikawati (2014) pada penelitian kualitatif didapatkan data bahwa Angka Kematian Bayi (AKB) di Sulawesi Utara naik dari tahun 2012 yang berjumlah 49 kasus menjadi 77 kasus di tahun 2013. Salah satu penyebab naiknya angka kasus kematian bayi ini adalah karena berat badan rendah (BBR) akibat kurang gizi. Menurut hasil wawancara dengan Dinas Kesehatan bagian Ibu dan Anak, di Provinsi Sulawesi Utara salah satu dampak signifikan dari pernikahan anak adalah ibu muda tidak tahu atau tidak memahami masalah kehamilan, sehingga terkadang anak yang dilahirkan menjadi kurang gizi hingga menyebabkan berat badan rendah (BBR) dan akhirnya meninggal setelah dilahirkan. Selain itu, Angka Kematian Ibu (AKI) juga menjadi salah satu dampak dari adanya perkawinan anak di Sulawesi Utara.

Perempuan yang hamil dan melahirkan pada usia 10-14 tahun memiliki resiko 5x lebih besar dibandingkan dengan perempuan yang hamil di usia 20-24 tahun. Disebutkan 
bahwa anak perempuan berusia 10-14 tahun berisiko lima kali lipat meninggal saat hamil maupun bersalin dibandingkan kelompok usia 20-24 tahun, sementara risiko ini meningkat dua kali lipat pada kelompok usia 15-19 tahun. Angka kematian ibu usia dibawah 16 tahun di Kamerun, Etiopia, dan Nigeria, bahkan lebih tinggi hingga enam kali lipat (Fadlyana, 2016).

Penelitian ini sejalan dengan penelitian yang dilakukan oleh Djamilah (2014) pada penelitian kualitatif didapatkan kasus pernikahan dini dari Data Pengadilan Tinggi Agama Kalimantan Selatan menunjukkan bahwa kasus tertinggi pada tahun 2012 terjadi di Hulu sungai Tengah dengan kasus 78 pernikahan dini, 20 diantaranya dialami oleh perempuan dan 58 dialami oleh lakilaki. Di kabupaten Banjar, Kalimantan Selatan ditemukan kasus dimana ibu hamil yang belum cukup umur mengalami kematian karena organ reproduksinya belum siap selain itu karena mereka tidak paham tentang kesehatan reproduksi.

Paket "Remaja Sehat" sebagai salah satu bentuk upaya preventif dan promotif yang bertujuan untuk menjelaskan dan membahas terkait dampak pernikahan usia dini pada sistem reproduksi. Isi dari paket ini meliputi: menjelaskan arti dari pernikahan usia dini, resiko pernikahan usia dini, resiko kehamilan usia remaja dibawah usia 20 tahun, dan pencegahan pernikahan usia dini.

Paket "Remaja Sehat" ini juga diharapkan dapat mendukung program Pemerintah Kabupaten Cilacap mengenai Penerapan Komitmen Pendewasaan Usia Pernikahan guna untuk menekan akan pernikahan usia muda di Wilayah Kabupaten Cilacap.

Penelitian ini sejalan dengan penelitian yang dilakukan oleh Riska (2012) dengan judul "Gambaran Pengetahuan Remaja Putri Tentang Risiko Pernikahan Dini Terhadap Kehamilan dan Persalinan di SMA N 1 Sinjai Utara" Berdasarkan hasil penelitian yang dilakukan di SMA Negeri I Sinjai Utara menunjukkan bahwa dari 97 siswi, terdapat responden $89(91,76 \%)$ yang tahu tentang rsiko pernikahan dini terhadap kehamilan, danresponden $8(8,24 \%)$ yang tidak tahu tentang risiko pernikahan dini terhadap kehamilan.

\section{Pengaruh "Paket Remaja Sehat" Terhadap Sikap Remaja Tentang Dampak Pernikahan Usia Dini}

Berdasarkan hasil dari analisis data diperoleh nilai rata-rata sikap responden sebelum diberikan paket remaja sehat adalah 1,81 dan sesudah diberikan paket remaja sehat adalah 1,97. Hasil uji statistik paired t-test didapatkan nilai $p$-value $=$ $0,001(p<0.05)$ yang berarti ada pengaruh 
paket remaja sehat terhadap sikap remaja tentang dampak pernikahan usia dini di Wilayah Kecamatan Majenang, Kabupaten Cilacap, Provinsi Jawa Tengah tahun 2020.

Sikap merupakan faktor yang ada dalam diri manusia yang dapat mendorong atau menimbulkan perilaku tertentu. Jadi, jika seorang remaja mempunyai sikap yang baik terhadap dampak pernikahan usia dini pada sistem reproduksi perempuan maka akan melahirkan perilaku yang baik pula terhadap penyikapan pencegahan pernikahan usia dini. Sikap dapat diartikan sebagai kesiapan/kesediaan responden dalam bertindak tetapi belum melaksanakan. Proses ini tidak langsung terjadi dengan sendirinya, tetapi ada beberapa tahap salah satunya dengan proses belajar. Proses belajar ini terjadi karena pengalaman seseorang dengan objek tertentu, dengan menghubungkan pengalaman yang satu dengan pengalaman lainnya. Dengan banyaknya pengalaman yang diperoleh dapat membantu seseorang untuk menentukan sikap terhadap tindakan yang akan dia lakukan.

Nilai sikap responden setelah diberikan paket remaja sehat mayoritas menjadi meningkat. Hal ini dikarenakan responden masih mampu menangkap seluruh hal positif yang didapatkan dari paket remaja sehat tersebut. Setelah pengetahuan responden meningkat, emosional responden bereaksi dengan stimulus yang ada. Selain itu, pendidikan kesehatan tentang paket remaja sehat diharapkan mampu meningkatkan pengetahuan remaja, sehingga remaja memiliki sikap positif yaitu mampu menerapkan gaya hidup sehat, menjaga organ reproduksi perempuan dan mampu menerapkan pencegahan pernikahan di usia dini. Responden yang bersikap tidak baik mampu mengubah sikapnya menjadi baik setelah diberikan intervensi.

Hal ini sesuai dengan penelitian yang dilakukan oleh Husna (2014), mengemukan bahwa ada perbedaan sikap mengenai pernikahan dini sebelum dan setelah diberikan penyuluhan Pendewasaan Usia Pernikahan.

Menurut Azwar (2012), sikap mempunyai 3 komponen pokok yaitu kepercayaan/pemikiran (kognitif), kehidupan emosional (afeksi), dan kecenderungan untuk bertindak (konasi). Ketiga komponen tersebut secara bersamasama membentuk sikap yang utuh. Dalam menentukan sikap yang utuh ini, pengetahuan, pikiran, keyakinan, dan emosi memegang peranan penting. Misalnya : remaja yang tahu tentang dampak negatif pernikahan usia dini pada sistem reproduksi perempuan. Pengetahuan ini akan membawa remaja untuk berpikir akan pentingnya 
kematangan sistem reproduksi sebelum menikah untuk menghindari dampak negatif seperti terjadinya kanker serviks dan kanker payudara di masa yang akan datang. Serta memahami akan pentingnya kematangan emosional ketika akan menikah guna menekan angka perceraian di Indonesia, khususnya angka kejadian di wilayah Kecamatan Majenang, Kabupaten Cilacap. Meskipun terkadang pengetahuan seseorang masih kurang, namun banyak cara untuk menambah wawasan, seperti yang telah disebutkan proses belajar dan pengalaman orang lain. Dan yang terpenting komponen emosi dan keyakinan ikut bekerja sehingga remaja tersebut berniat (kecenderungan bertindak) untuk menentukan sikap remaja terhadap penyikapan dampak pernikahan usia dini pada sistem reproduksi perempuan

\section{KESIMPULAN}

Mayoritas usia responden adalah 18 tahun (44.8\%), Mayoritas pendidikan responden adalah pendidikan SMA $(88.1 \%)$. Semua responden sudah berpengalaman (100.0\%) dan mayoritas memperoleh informasi dari internet (58.2\%). Ada pengaruh yang signifikan antara paket remaja sehat terhadap pengetahuan remaja tentang dampak pernikahan usia dini di Wilayah Kecamatan Majenang, Kabupaten Cilacap, Provinsi Jawa Tengah tahun 2020. Hal ini ditunjukkan dari hasil uji statistik menggunakan paired t test dengan nilai $p$ value sebesar 0,000 ( $p<0,005)$. Ada pengaruh yang signifikan antara paket remaja sehat terhadap sikap remaja tentang dampak pernikahan usia dini di Wilayah Kecamatan Majenang, Kabupaten Cilacap, Provinsi Jawa Tengah tahun 2020. Hal ini ditunjukkan dari hasil uji statistik menggunakan paired $t$ test dengan nilai $p$ value sebesar 0,001 ( $p<0,005)$.

\section{DAFTAR PUSTAKA}

Alligood \& Raile. (2017). Pakar Teori Keperawatan. Vol. 2. Singapore : Elsevier, 116-132

Arosna, A. D. Pengaruh Pendidikan Kesehatan Reproduksi Terhadap Pengetahuan dan Sikap Mahasiswa di FIK-UMS(Skripsi).Surakarta: Universitas Muhammadiyah Surakarta; 2014.

Ernawati, Hery (2015). Pemanfaatan Orang Tua Sebagai Sumber Informasi Kesehatan Reproduksi Remaja di Daerah Pedesaan. Prosiding Poltekkes Kemenkes Surabaya.

Follona, Maryanah, \& Meilan. (2018). Kesehatan Reproduksi Remaja : Implementasi PKPR Dalam Teman Sebaya, Malang : Wineka Pedia.

Hasanah, H. Pemahaman Kesehatan Reproduksi Bagi Perempuan. Jurnal SAWWA. 2016;11.

Hurlock, E.B (2009). Psikologi Perkembangan Suatu Pendekatan Sepanjang Rentang Kehidupan. Edisi 5. Jakarta : Erlangga.

Imron, A. 2012. Pendidikan Kesehatan Reproduksi Remaja: PEER EDUCATOR \& Efektivitas Program PIK-KKR di sekolah. Jogjakarta: ArRuzz Media.

Kompasiana. (2019). Aspek Persiapan 
Peran Orangtua di Usia Remaja, dilihat dari http://www.kompasiana.com/listalyla 15bb4e1d9ab12ae23103654f4/perenc anaan-menjadi-orang-tua-di-usiaremaja, diakses pada tanggal 2 januari 2020.

Kumalasari, I \& Andhyantoro, I. 2012. Kesehatan Reproduksi untuk mahasiswa kebidanan dan keperawatan. Jakarta: Salemba Medika.

Kusmirah, E (2012). Kesehatan Reproduksi Remaja dan Wanita. Jakarta : Salemba Medika.

LN, Syamsu Yusuf. 2008. Psikologi Perkembangan Anak \& Remaja. Bandung: PT. Remaja Rosdakarya.

Lowdermilk, Bobak. (2014). Buku Ajaran Keperawatan Maternitas. Ed. 4, Jakarta : EGC

Lowdermilk, Perry \& Cashion. (2013). Keperawatan Maternitas. Ed. 8. Singapore : Elsevier, 54-62

Lubis \& Pieter (2010). Pengantar Psikologi Untuk Kebidanan. Jakarta : Prenada Media

Notoadmodjo, S. 2007. Promosi Kesehatan Teori dan Aplikasinya. Jakarta: Rineka cipta.

Notoadmojo, S. 2010. Promosi Kesehatan Teori \& Aplikasinya, Edisi Revisi. Jakarta: Rineka Cipta.

Notoatmodjo \& Soekidjo. (2012). Metodelogi Penelitian Kesehatan. Bhineka Cipta, Jakarta

Nursalam. (2015). Metode Penelitian Ilmu Keperawatan. Ed.4, Jakarta : Salemba Medika

Ristraningsih, G. P. Pengaruh Pendidikan Kesehatan Terhadap Tingkat Pengetahuan Kesehatan Reproduksi Remaja Pada Siswi Kelas VIII Di SMP Negeri 28 Semarang. Surakarta: Universitas Muhammadiyah Surakarta; 2017.

Salmah. (2006). Asuhan Kebidanan Antenatal. Jakarta : EGC

Setianti, Y dan Komala, L (2013).
Komunikasi Kesehatan Reproduksi Remaja di Pedesaan. Edutech, Tahun 12, Bol. 1, No. 3, Oktober

Sugiyono. (2010). Metode Penelitian Kuantitatif Kualitatif dan $R \& D$, Bandung, Alfabeta

Susanti. (2008). Psikologi Kehamilan. Jakarta : Salemba Medika 
Tabel 1. Distribusi Frekuensi Responden di Wilayah Kecamatan Majenang, Kabupaten Cilacap, Provinsi Jawa Tengah

\begin{tabular}{|c|c|c|}
\hline Variabel & Frekuensi (n) & Persentase (\%) \\
\hline \multicolumn{3}{|l|}{ Usia } \\
\hline 17 Tahun & 8 & 11,9 \\
\hline 18 Tahun & 30 & 44,8 \\
\hline 19 Tahun & 29 & 43,3 \\
\hline \multicolumn{3}{|l|}{ Pendidikan } \\
\hline SMP & 8 & 11,9 \\
\hline SMA & 59 & 88,1 \\
\hline \multicolumn{3}{|l|}{ Pengalaman } \\
\hline $\mathrm{Ya}$ & 67 & 100,0 \\
\hline Tidak & 0 & 0 \\
\hline \multicolumn{3}{|l|}{ Sumber Informasi } \\
\hline Sekolah & 21 & 31,3 \\
\hline Internet & 39 & 58,2 \\
\hline Teman/Tetangga atau & 7 & 10,4 \\
\hline Keluarga & & \\
\hline
\end{tabular}

Tabel 2. Distribusi Frekuensi Responden Berdasarkan Pre-Test dan Post-Test Pengetahuan di Wilayah Kecamatan Majenang, Kabupaten Cilacap, Provinsi Jawa Tengah

\begin{tabular}{lcc}
\hline \multicolumn{1}{c}{ Pengetahuan } & $\begin{array}{c}\text { Frekuensi } \\
(\mathbf{n})\end{array}$ & Persentase (\%) \\
\hline $\begin{array}{l}\text { Pre Test } \\
\text { Pengetahuan Baik }\end{array}$ & 4 & 6,0 \\
$\begin{array}{l}\text { Pengetahuan } \\
\text { Cukup }\end{array}$ & 52 & 77,6 \\
$\begin{array}{l}\text { Pengetahuan } \\
\text { Kurang }\end{array}$ & 11 & 16,4 \\
$\quad$ Post Test & & \\
Pengetahuan Baik & 52 & 77,6 \\
$\begin{array}{l}\text { Pengetahuan } \\
\text { Cukup }\end{array}$ & 13 & 19,4 \\
Pengetahuan & 2 & 3,0 \\
Kurang & & \\
\hline
\end{tabular}


Tabel 3. Distribusi Frekuensi Responden Berdasarkan Pre-Test dan Post Test Sikap di Wilayah Kecamatan Majenang, Kabupaten Cilacap, Provinsi Jawa Tengah

\begin{tabular}{lcc}
\hline \multicolumn{1}{c}{ Sikap } & Frekuensi (n) & Persentase (\%) \\
\hline Pre Test & & \\
Baik & 54 & 80,6 \\
Tidak Baik & 13 & 19,4 \\
Post Test & & \\
Baik & 65 & 97,0 \\
Tidak Baik & 2 & 3,0 \\
\hline
\end{tabular}

Tabel 4. Gambaran Hasil Uji Normalitas Data pada Variabel Pengetahuan dan Sikap Remaja di Wilayah Kecamatan Majenang, Kabupaten Cilacap, Provinsi Jawa Tengah

\begin{tabular}{|c|c|}
\hline Variabel & $\begin{array}{c}\text { P value } \\
\text { Klomogrov-Smirnov }\end{array}$ \\
\hline $\begin{array}{lr}\text { Pengetahuan } & \text { Remaja } \\
\text { sebelum diberikan Paket } \\
\text { Remaja Sehat }\end{array}$ & 0,469 \\
\hline $\begin{array}{l}\text { Pengetahuan Remaja } \\
\text { sesudah diberikan Paket }\end{array}$ & 0,425 \\
\hline $\begin{array}{lcr}\text { Sikap } & \text { Remaja } & \text { sebelum } \\
\text { diberikan } & \text { Paket } & \text { Remaja } \\
\text { Sehat } & & \end{array}$ & 0,203 \\
\hline $\begin{array}{lcc}\text { Sikap } & \text { Remaja } & \text { sesudah } \\
\text { diberikan } & \text { Paket } & \text { Remaja } \\
\text { Sehat } & & \end{array}$ & 0,195 \\
\hline
\end{tabular}

Tabel 5. Pengaruh Pengetahun Remaja Pre-Test dan Post-Test di Wilayah Kecamatan Majenang, Kabupaten Cilacap, Provinsi Jawa Tengah

\begin{tabular}{lccccc}
\hline Pengetahuan & Mean & N & Standar Deviasi & $\mathbf{9 5 \%}$ CI & P(Value) \\
\hline Pre Test & 1,90 & 67 & 0,465 & $0,745-$ & 0,000 \\
Post Test & 2,75 & 67 & 0,503 & 0,957 & \\
\hline
\end{tabular}

Tabel 6. Sikap Remaja Pre-Test dan Post-Test Pemberian Pendidikan Kesehatan Paket Remaja Sehat di Wilayah Kecamatan Majenang, Kabupaten Cilacap, Provinsi Jawa Tengah

\begin{tabular}{cccccc}
\hline Sikap & Mean & $\mathbf{N}$ & $\begin{array}{c}\text { Standar } \\
\text { Deviasi }\end{array}$ & $\mathbf{9 5 \%} \mathbf{C I}$ & P(Value) \\
\hline Pre Test & 1,81 & 67 & 0,398 & $0,073-0,255$ & 0,001 \\
Post Test & 1,97 & 67 & 0,171 & & \\
\hline
\end{tabular}

